\title{
ANALISIS PEMBUATAN ASAM LEMAK HIDROKSAMAT DARI MINYAK KELAPA MELALUI METODE ENZIMATIS
}

\author{
Muhsinun \\ Program Studi Pendidikan Ilmu Pengetahuan Alam, Institut Pendidikan Nusantara Global, Praya - NTB \\ Corresponding Author: cinun.chemist@gmail.com
}

\begin{abstract}
ABSTRAK: Secara umum, asam lemak hidroksamat (Fatty Hydroxamic Acids/FHA) di sintesis dari bahan dasar yang mengandung asam lemak. Salah satu sumber asam lemak adalah minyak kelapa. Minyak kelapa mengandung asam lemak dengan rantai sedang dan panjang sehingga memiliki potensi yang sangat besar sebagai bahan baku sintesis asam lemak hidroksamat. Adapun tujuan dari penelitian ini adalah untuk mensintesis FHA dari minyak kelapa secara enzimatis dan mengetahui jumlah produk FHA yang dihasilkan. Metode yang digunakan adalah metode enzimatis yang meliputi beberapa tahap pengerjaan yaitu tahap sintesis, tahap perbanyakan, dan tahap pemurnian. Dari hasil penelitian, diperoleh persentase hasil sintesis asam lemak hidroksamat dari minyak kelapa setelah dilakukan perbanyakan dengan menggunakan kondisi sintesisnya adalah sekitar 48,58\%. Jumlah gugus asam hidroksamat dalam 1 gram sampel kering asam lemak hidroksamat adalah 2,97 mmol. Jadi dari kedua hasil tersebut di atas, disimpulkan bahwa asam lemak hidroksamat dapat disintesis dari minyak kelapa.
\end{abstract}

Kata kunci: sintesis, asam lemak hidroksamat, FHA, minyak kelapa, enzimatis

ABSTRACT: Generally, fatty hydroxamic acids (FHA) are synthesized from basic ingredients containing fatty acids. Fatty acids can be obtained from coconut oil among several other sources. Coconut oil contains fatty acids with medium and long chains so it has enormous potential as a raw material for the synthesis of hydroxamic fatty acids. The purpose of this research is to synthesize FHA from coconut oil enzymatically and determine the amount of FHA products produced. The method used is the enzymatic method which includes several stages of work, namely the synthesis stage, the multiplication stage, and the purification stage. From the research results, the percentage obtained from the synthesis was around $48.58 \%$ of hydroxamic fatty acids from coconut oil after propagation using the synthesis conditions. The number of hydroxamic acid groups in 1 gram of dry hydroxamic fatty acid sample was $2.97 \mathrm{mmol}$. Thus, from the two results mentioned above, it was concluded that hydroxamic fatty acids can be synthesized from coconut oil.

Keywords: synthesis, fatty hydroxamic acids, FHA, coconut oil, enzymatic

\section{PENDAHULUAN}

Asam lemak hidroksamat (Fatty
Hydroxamic Acids/FHA) dengan rumus
molekul R-CO-NH-OH (R = alkyl atau aril)
(Lee et al., 2001) merupakan senyawa yang
bernilai ekonomis tinggi karena mempunyai
banyak manfaat. Turunan asam lemak
hidroksamat telah banyak mendapatkan
perhatian mengenai aktivitas biologisnya
yaitu sebagai faktor pertumbuhan, bahan
tambahan pada makanan, antibiotik,
antijamur, faktor pembelahan sel, penghambat
enzim, penghambatan matrix
metalloproteinase (MMP), penghambat tumor
dan kanker. Kompleksnya dengan beberapa
ion logam telah digunakan dalam kimia
analitik sebagai reagen untuk gravimetri,

spektrofotometri logam, pengkhelat untuk mineral bumi yang langka dan untuk pengekstrak ion-ion logam dari fase air. Monomer dan polimernya juga telah digunakan untuk pemisahan ion-ion logam. Selain itu, FHA juga telah dimanfaatkan sebagai surfaktan pada industri sabun cuci. Walaupun demikian, ketersediaannya di pasaran sangat terbatas, hanya berupa FHA dengan rantai pendek, sedangkan FHA dengan rantai sedang dan panjang belum banyak tersedia. Oleh sebab itu, sangat perlu dilakukan sintesis FHA dengan rantai sedang dan panjang tersebut.

Secara umum, FHA dapat disintesis dari bahan baku asam lemak. Salah satu sumber 
asam lemak adalah minyak kelapa. Minyak kelapa mengandung asam lemak dengan rantai sedang dan panjang. Oleh sebab itu, minyak kelapa memiliki potensi yang sangat besar sebagai bahan baku sintesis FHA. Ada dua cara untuk mensintesis asam lemak hidroksamat yaitu cara kimia dan enzimatis. Cara kimia memiliki kekurangan yaitu reaksinya tidak spesifik dan sering menyebabkan terdekomposisinya produk reaksi. Sedangkan cara enzimatis memiliki kelebihan yaitu reaksinya spesifik, enansioslektif, tidak menyebabkan terdekomposisnya produk reaksi dan memudahkan dalam pemurnian. Oleh sebab itu, penelitian sintesis asam lemak hidroksamat dari minyak kelapa ini dilakukan dengan cara enzimatis.

Seperti diketahui, minyak kelapa tersedia melimpah di Indonesia dan menjadi komoditi ekspor Indonesia sehingga minyak kelapa memiliki potensi yang sangat besar sebagai bahan baku untuk sintesis asam lemak hidroksamat dengan rantai sedang dan panjang. Untuk pembuktiannya sangat perlu dilakukan penelitian tentang sintesis asam lemak hidroksamat dengan rantai sedang dan panjang dari minyak kelapa ini, dengan harapan nilai ekonomis dari minyak kelapa dapat meningkat baik di pasar lokal maupun internasional.

\section{METODOLOGI PENELITIAN}

\section{Alat dan Bahan}

Adapun peralatan yang digunakan dalam penelitian, yaitu semua peralatan dasar dari gelas di laboratorium kimia, magnetic stirrer-pemanas, magnetic bar, shaker, pompa vakum, timbangan digital, statif-klem, $\mathrm{pH}$ meter digital. Adapun bahan yang digunakan berderajat P.A (Pro Analyze) kecuali yang disebut khusus. Bahan tersebut adalah sebagai berikut: n-heksana, minyak kelapa, hidroksilamin hidroklorida, enzim Lipase, buffer asetat, $\mathrm{NaOH}, \mathrm{HCl}$, Aquades, $\mathrm{pH}$ universal Merck dan kertas saring Whatman.

\section{Sintesis FHA}

Proses sintesis FHA dari minyak kelapa menggunakan mekanisme enzim. Adapun prosedur kerja secara lengkapnya adalah sebagai berikut:
FHA di sintesis berdasarkan metode enzimatis (Suhendra et al., 2005). Reaksi pembuatan dilakukan dengan mereaksikan sejumlah 1,5 gram minyak kelapa yang dilarutkan dalam $15 \mathrm{~mL}$ n-heksana dengan $10 \mathrm{mmol}$ hidroksilamin hidroklorida dalam $100 \mathrm{~mL}$ pada erlenmeyer yang tertutup dengan bantuan katalis enzim lipase. Campuran kemudian distirrer dengan kecepatan 100 rpm. FHA yang terbentuk diantara lapisan airheksan, dipisahkan dari air dan lipase dengan filtrasi. Untuk mendapatkan FHA padat, fraksi n-heksana didinginkan dalam pendingin $\left(<5{ }^{\circ} \mathrm{C}\right)$ selama 5 jam. Kemudian disaring dan dicuci dengan n-heksana beberapa kali dan dikeringkan dalam vaccum desicator yang berisi Fosfor pentoksida selama 24 jam.

\section{Perbanyakan (Scaling $U p$ )}

Perbanyakan pembuatan FHA dilakukan sebanyak tiga kali dari perbandingan semula dengan menggunakan perbandingan kondisi sintesis yang telah digunakan sebelumnya. Campuran tersebut kemudian diinkubasi selama 25 jam dengan kecepatan putaran 100 rpm pada suhu $35{ }^{\circ} \mathrm{C}$. Jumlah asam lemak hidroksamat yang terbentuk ditentukan dengan menimbang FHA yang sudah dimurnikan dengan menggunakan timbangan analitik.

\section{Pemurnian}

FHA yang terbentuk pada lapisan nheksan-air dipisahkan dari lipase dengan filtrasi vakum pada suhu $65{ }^{\circ} \mathrm{C}$. Fase air yang terdapat di bawah lapisan fraksi n-heksan kemudian dipisahkan dengan corong pisah. Untuk mendapatkan FHA padat, fraksi nheksan didinginkan dalam freezer $\left(<-5{ }^{\circ} \mathrm{C}\right)$ selama 5 jam dan difiltrasi. FHA yang terdapat pada kertas saring dicuci dengan nheksan sebanyak 3 kali dan dikeringkan dalam desikator yang telah diisi dengan fosfor pentaoksida selam 24 jam.

\section{HASIL DAN PEMBAHASAN}

Pada tahap sintesis ini, kedua substrat (minyak kelapa dan hidroksilamin) enzim lipase dilarutkan dalam pelarut yang berbeda yaitu minyak kelapa dilarutkan dalam $n$ heksan dengan perbandingan $1: 10$ (gram : $\mathrm{mL}$ ), sedangkan hidrosilamin dilarutkan dalam air dengan perbandingan $1: 1$ ( $\mathrm{mmol}$ : 
mL). Pemilihan n-heksan sebagai pelarut minyak kelapa didasarkan atas pertimbangan bahwa pelarut yang memberikan hasil yang terbaik untuk sintesis FHA dari minyak nabati adalah n-heksan (Suhendra et al., 2005). Sedangkan pemilihan air untuk melarutkan hidroksilamin dipertimbangkan atas kemampuannya yang tinggi untuk melarutkan hidroksilamin. Karena semakin tinggi kelarutan suatu zat maka kecepatan reaksi juga semakin cepat. Selain itu, penggunaan air sebagai pelarut hidroksilamin dipertimbangkan atas ketersediaanya yang melimpah, murah, tidak memberikan produk sampingan dan tentunya memudahkan untuk proses pemurnian produk yang diinginkan.

Berdasarkan hasil pengamatan, ketika semua reaktan dicampur dalam satu wadah terbentuk dua lapisan dimana lapisan atas merupakan lapisan n-heksan yang mengandung minyak dan lapisan bawah merupakan lapisan air yang mengandung hidroksilamin. Pembentukan dua lapisan ini disebabkan karena n-heksan tidak bisa bercampur dengan air. Hal ini disebabkan oleh perbedaan kepolaran dari kedua pelarut substrat tersebut. N-heksan terletak di lapisan atas karena n-heksan memiliki massa jenis yang lebih kecil $\left(\rho=0,66 \mathrm{gram} / \mathrm{cm}^{3}\right)$ daripada air $\left(\rho=0,997 \mathrm{gram} / \mathrm{cm}^{3}\right)$ pada suhu $298 \mathrm{~K}$ (Tikhonov, 2010). Lipase sendiri merupakan katalis yang besifat polar dan memiliki kelarutan yang tinggi dalam air. Namun, karena sudah berbentuk immobilized lipase, maka lipase menjadi tidak larut dan berada di antara lapisan n-heksan dan air.

Setelah proses reaksi selesai, didapatkan warna kedua pelarut menjadi keruh dimana pada lapisan air terbentuk warna keruh kecoklatan, sedangkan pada lapisan n-heksan terbentuk warna keruh keputihan. Pembentukan warna keruh kecoklatan pada lapisan air disebabkan oleh terpecahnya padatan enzim lipase yang berwarna cokelat menjadi partikel-partikel kecil yang terdispersi secara merata dalam air, sedangkan terbentuknya warna keruh keputihan pada lapisan n-heksan disebabkan oleh terbentuknya produk baru yaitu, FHA yang larut dalam n-heksan. Apabila produk reaksi tersebut dibiarkan mendingin pada suhu kamar, maka pada lapisan n-heksan akan terbentuk produk berwarna putih yang merupakan FHA. Pembentukan produk berwarna putih tersebut disebabkan oleh menurunnya kelarutan FHA dalam n-heksan yang disebabkan oleh turunnya temperatur pada sistem reaksi oleh proses pendinginan (Isha et al, 2007).

Apabila ditinjau dari produk reaksi dan komposisi kimia minyak kelapa, maka pada proses penghidroksilaminolisisan minyak kelapa terjadi reaksi antara trigliserida dan hidroksilamin dengan menghasilkan produk reaksi berupa FHA dan gliserol. Reaksi penghidroksilaminolisisan trigliserida tersebut terjadi diantara lapisan n-heksan dan lapisan air. Karena bagaimanapun, trigliserida larut dalam n-heksan dan hidroksilamin larut dalam air dan rekasi maksimum terjadi diantara lapisan air dan n-heksan tersebut (Blattner, 2005).

Pada tahap perbanyakan, dihasilkan FHA dengan persentase 48,58\%. Namun, persentase hasil sintesis ini masih rendah bila dibandingkan dengan persentase hasil sintesis asam lemak hidroksamat dari minyak kelapa sawit yaitu sebesar 89\% (Suhendra et al., 2005). Rendahnya persentase hasil sintesis asam lemak hidroksamat ini dipengaruhi oleh komposisi kimia dari minyak kelapa. Seperti diketahui, asam lemak dengan rantai sedang memiliki kelarutan lebih tinggi dalam air daripada asam lemak dengan rantai panjang. Hal ini mengakibatkan asam lemak dengan rantai sedang menjadi lebih sulit diubah menjadi asam lemak hidroksamat, karena sisi aktif enzim lipase tertutup dalam air (Blattner, 2005).

Analisis kuantitatif asam lemak hidroksamat yang terbentuk dilakukan dengan penentuan jumlah total $\mathrm{N}$ yang terkandung dalam asam lemak hidroksamat kering dengan menggunakan metode Semi Makro Kjeldahl. Berdasarkan hasil analisis, jumlah total $\mathrm{N}$ yang terkandung dalam sampel asam lemak hidroksamat kering adalah 4,18\%. Ini berarti bahwa terdapat 2,97 mmol gugus asam lemak hidroksamat dalam 1 gram sampel asam 
lemak hidroksamat kering hasil sintesis dari minyak kelapa.

\section{KESIMPULAN}

Berdasarkan hasil penelitian dan kajian pustaka yang telah dilakukan, maka dapat disimpulkan bahwa asam lemak hidroksamat dapat disintesis menggunakan bahan baku asam lemak yang terkandung dalam minyak kelapa. Setelah dilakukan pemurnian, diperoleh fasa berbentuk padat dan berwarna putih yang merupakan hasil akhir penelitian ini, yaitu asam lemak hidroksamat. Dari hasil penelitian, diperoleh persentase hasil sintesis asam lemak hidroksamat dari minyak kelapa setelah dilakukan perbanyakan dengan menggunakan perbandingan kondisi sintesisnya adalah sekitar 48,58\%. Jumlah gugus asam hidroksamat dalam 1 gram sampel kering asam lemak hidroksamat adalah 2,97 mmol.

\section{DAFTAR PUSTAKA}

Blattner, C. 2005. Biocatalysis using lipase immobilised in organogels in supercritical carbon dioxide. Disertasi. University of Regensburg.

Isha, A., Yusof, N.A., Ahmad, M., Suhendra, D., Yunus, W.M.Z.W. dan Zainal, Z. 2007. Optical Fibre Chemical Sensor For Trace Vanadium(V) Determination Based On Newly Synthesized Palm Based Fatty Hydroxamic Acid Immobilized In Polyvinyl Chloride Membrane. Spectrochimica Acta Part A: Molecular and Biomolecular Spectroscopy. 67 (5):1398-1402.

Lee, T., Jeon, D., Kim, J., Hong, S. 2001. Formation of metal complex in a poly(hydroxamic acid) resin bead. Fibers and Polymers. 2 (1): 13-17.

Suhendra, D., Yunus, W.M.Z.W., Haron, M. J., Basri, M. dan Silong, S. 2005. Enzymatic Synthesis of Fatty Hydroxamic Acid From Palm Oil. Journal of Oleo Science. 54(1):33-38.

Tikhonov, A.M. 2010. The Critical Crossover at the n-Hexane-Water Interface. Journal of Experimental and Theoretical Physics. 110(6):10551057. 